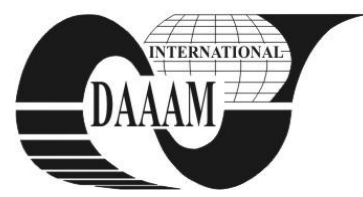

Annals of DAAAM for 2011 \& Proceedings of the 22nd International DAAAM Symposium, Volume 22, No. 1, ISSN 1726-9679 ISBN 978-3-901509-83-4, Editor B. Katalinic, Published by DAAAM International, Vienna, Austria, EU, 2011 Make Harmony between Technology and Nature, and Your Mind will Fly Free as a Bird

\title{
LOGISTIC APPROACHES TO PORT MANAGEMENT SYSTEM
}

\author{
ORLIC PROTEGA, A[drijana]; ROGIC, K[ristijan] \& VRDOLJAK, J[asminka]
}

\begin{abstract}
The market developments as well as the everchanging environment in which ports operate created the need to different approaches to port's perspective as an important part of wider logistic network. The complexity of port operation requires a systemic approach in studying the structure of its management system, basic operative tasks, as well as the scope of port logistic services. In this article the authors are presenting different logistic approaches in recent literature that emphasise the importance of port integration in supply chain as well as organization integration and partnership between port and users through emerging concepts such as Port Logistics Platform, Port Centric Logistics and Integrated Logistics. Literature analysys will lead to conceptual framework for research that will take place in Port of Ploče, Port of Vukovar and Port of Koper in order to develop an improved model of port management system with higher level of efficiency of port processes.
\end{abstract}

Key words: port management system, port centric logistics, port logistics platform, integrated logistics

\section{INTRODUCTION}

Today, ports have gained an important role in global commerce and are recognised as vital components in determining the overall competitiveness of national economies. Globalisation in shipping and trade has resulted in increasing pressure on ports to improve operational efficiency and provide wider range of logistic services (Mlinarić, T. J., Rogić, K, 2006). In recent literature, respectable number of authors among researchers, scholars, and representatives of port authorities emphasise the need to change the perception and clarify the role of ports in modern logistics (Ivaković Č., Rogić, K., Orlić Protega, A, 2008). Robinson (2002) suggests that the role of ports must be defined within a paradigm of ports as elements in value-driven chain systems. That definition has special importance due to the fact that it is now accepted that supply chains are the basis of most marketplace competition (Christopher, M., 1992), with Panayides (2006) notes that demand for maritime transport should be integrated and emanating from the need to minimise costs, improve reliability and add value in transport of goods form the point of production to the point of consumption.

\section{PORT CENTRIC LOGISTICS}

In the last few years, especially during the economic downturn, some ports encouraged companies to locate distribution centres at ports rather than in their traditional and usual inland locations. That was due to the fact that most of the freight that passses through these distribution centres first passes through a port (Mangan, J., Lalwani, C. and Fynes, B., 2008), afterwards transported hundreds of miles inland, and in case of containers - only for them to be returned to the port, at a similar cost. The key principles of PortCentric Logistics are unloading the container within the port itself or adjacend to the port; restituting the containers at the port - ready for the shipping line's next rotation; handling, storing and delivering the goods in the most efficient way and, if possible directly to the final destination. In case where intermediate storage/handling is required, the princeples imply ensuring that the goods are configured as required at the final destination. According to Mangan, Lalwani and Fynes (2008), in-port distribution centres approach is not in conflict with the regionalisation approach (connections to inland distrubution centres) (Notteboom and Rodrigue 2005) - depending upon the specific context, combinations of both of them would be valid.

\section{PORT LOGISTIC PLATFORM}

Ports position themselves between shippers and consignees, but also they represent an element embedded in value-driven chain systems. Interestingly, port logistics is more likely focused on the internal value added constellation in this stage, and more towards management functionality and interorganizational dimension (Song, D. W. and Panayides, P., 2008). This leads to the Port Logistic Platform in the Supply Chain Management with three key dimensions which are related to: logistics, inter-modal and information systems (Badi, A. and Kenth, L., 2008). Logistics system refers to features and facilities provided by port authority/terminal operator, which focus on the provision of superstructure and infrastructure for berthing and loading/unloading, temporary storage and intraport operations (Song, D.W. and Panayides, P., 2008). Intermodal system is an antecendent of the port networking system and also represents the transportation arm of the Port Logistic Platform. The information system is responsible for fastefficient planning, stowage, tracking of shipments and prenotification of port entry and departure (Bagchi, P. and Paik, S. $\mathrm{K} ., 2001$ ) and is often considered the major factor in the port organization affecting port operations (Helling, A. and Poister, T. H., 2000).

\section{INTEGRATED LOGISTICS}

Integrated logistics is defined as the process of anticipating customer needs and wants; acquiring the capital, materials, people, technologies, and information necessary to meet those needs and wants; optimizing the goods - or service - producing a network to fulfill customer requests; and utilizing the network to fulfill customer requests in a timely way (Little, A.D. 1991). It is a service-oriented process that helps move the product from the raw material source to the final customer. Integrated logistics has two subsets: primary logistics activities and service response logistics activities as noted in Figure 1. Primary logistics activities (transportation, facility structure, inventory, material handling and communication of information) help physically moving goods through the distribution channel. 


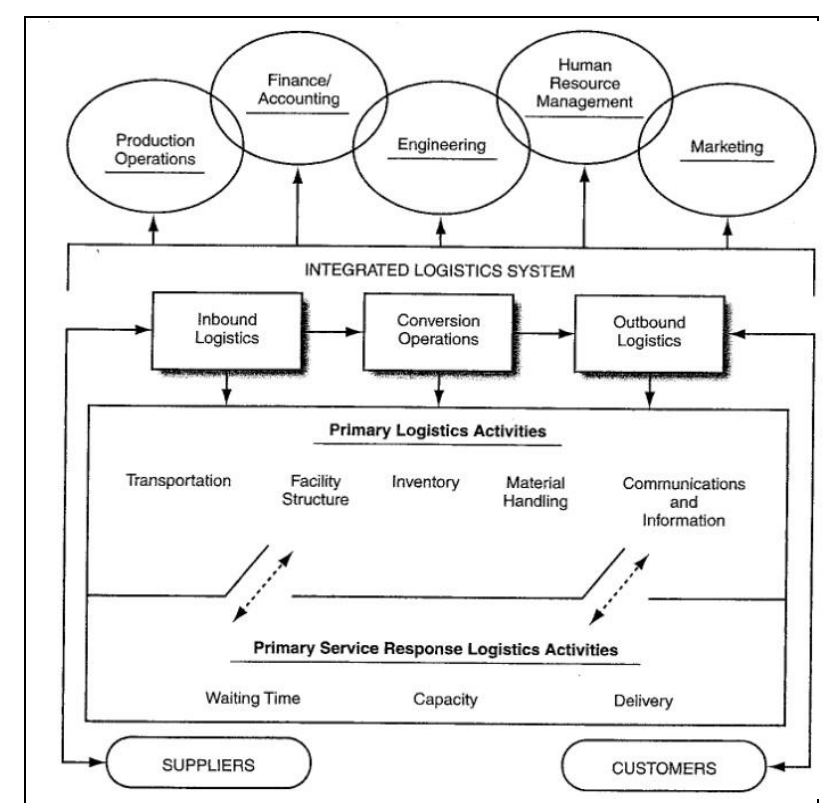

Fig. 1. The integrated Logistics Processes (Bloomberg D. J.; LeMay S.; Hanna J. B.: Logistics, Pearson Educational International, Prentice Hall, 2002, page 7)

Nonmaterial services move to customers at all levels of the distribution channel by way of service response logistics activities (waiting time, capacity and delivery). When those two subsets operate in conjunction with each other, they become integrated logistics (Bloomberg, D. J., LeMay, S. and Hanna, J.B., 2002). Integrated logistical support of operating and marketing strategies yields quality customer service, but its ability to support even broader and higher service strategies creates a sustainable and competitive advantage.

\section{CONCLUSION}

This paper presents the overview of literature that describes different approaches to introducing logistics into port management, presented by scientists and representatives of the port authority bodies. The review of different logistic approaches to the port's perspective showed that integrated logistics represents the best conceptual frame for improving port management system with higher level of effectiveness and efficiency of port processes and port's better integration in supply chains, and could include port-centric logistic approach as well as the Port Logistics Platform. Integrated logistics comprises both focusing on the continuing flow of physical products as well as the efficient movement of information, collection and storage of data, and communication with the parties involved in the business. The continuing flow of physical products is performed in three distinct operations: inbound logistics, conversion/operations, and outbound logistics through five primary logistics activities transportation, facility structure, inventory management and material handling. Efficient movement of information is performed throught three primary activities: waiting time, capacity and delivery. Those three service responsive logistics activities must operate together to meet customer service requirement, but they must also be in coordination with the rest of the logistics.

By selecting the concept of integral logistics to improve the port management system, the Port of Ploče, Port of Vukovar and Port of Koper will be studied. The aim of this research is the creation of an improved port management system according to the principles of integral logistics, that will contribute to the increase in the importance of the role of a port in the supply chain. The theses that support the realization of this goal are the following:

- Integral logistics includes the relations and processes that can contribute to greater success of the port management system, as well as improved port integration into the supply chain.;

- The port management system will be analysed in order to identify the bottlenecks and critical points;

Improvements in the area of bottlenecks achieved by the implementation of integral logistics can lead to the creation of a model of port management system improvement.

It will be possible to use the newly created model of port management system in the evaluation of the current port management systems, as support in developing new models of port management systems and in defining the preconditions for the improvement of logistic subsystems in ports.

\section{REFERENCES}

Badi, A.; Kenth, L. (2008). Port Logistic Platform in the Supply Chain Management, Proceedings of 3rd International Conference on Ports and Waterways POWA, Dubrovnik, Jolić, N. (Ed.), pp. 1-18, Faculty of Traffic and Transport Sciences University of Zagreb, Zagreb

Bagchi, P. K.; Paik, S. K. (2001). The role of public-private partnership in port information systems development, International Journal of Public Sector Management, Vol. 14, No. 6, pp. 482-499

Bloomberg, D. J.; LeMay, S. \& Hanna, J. B. (2002). Logistics, Pearson Educational International, Prentice Hall

Christopher, M. (1992). Logistics and Supply Chain Management, 1st ed. Financial Times/Pitman, London

Helling, A.; Poister, T. H. (2000). US maritime ports: trends, policy implications, and research needs, Economic Development Quaterly, Vol. 14, No. 3, pp. 298-315

Ivaković Č., Rogić, K. \& Orlić Protega, A. (2008). Traffic on the Croatian Inland Waterways in the Context of the European Programme NAIADES, Promet - Traffic \& Transportation, Vol. 20, No. 6, pp. 383-393, ISSN 03535320, Pardubice, Portorož, Sarajevo, Trieste, Zagreb, Žilina

Little, A. D.; (1991). Logistics in the Service Industries, Oak Book, IL: Council of Logistics Management, Pennsylvania

Mangan, J.; Lalwani, C. \& Fynes, B. (2008). Port-centric logistics, International Journal of Logistics Management Vol. 19, No. 1, pp. 29-41

Mlinarić, T. J.; Rogić, K. (2006). Methodology of Implementing Intermodal Transport in The Croatian Traffic System, Proceedings of 17th International DAAAM Symposium "Intelligent Manufacturing\&Automation: Focus on Mechatronics and Robotics", Vienna, Katalinic, B. (Ed.), pp. 255-256, DAAAM, Vienna

Notteboom, T.; Rodrigue, J. (2005). Port regionalisation: towards a new phase in port development, Maritime Policiy and Management, Vol. 32, pp 297-313, ISSN 1464-5254

Panayides, P. (2006). Maritime logistics and global supply chains: towards a research agenda, Maritime Economics and Logistics, Vol 8, pp. 3-18

Robinson, R. (2002). Ports as elements in value-driven chain systems: the new paradigm, Maritime Policy and Management, Vol 29, No. 3, p. 252, ISSN 1464-5254

Song, D. W.; Panayides, M. P. (2008). Global supply chain and port/terminal: integration and competitivnes, Maritime Policy and Management, Vol. 35, No.1, pp.73-87, ISSN 1464-5254 